Editorial

\title{
Research in infectious disease in wild birds
}

\section{Editorial}

One of the joys of teaching veterinary students, as I do, is to follow their career trajectories after they leave vet school. And so it is with great pleasure that I have watched as Becki Lawson has forged an exceptional research path in the field of wild bird disease. Back in 2014 the Zoological Society of London began the Garden Wildlife Health program, encouraging members of the public to report on animals with pathological conditions they found in their gardens. In those last five years Becki and her colleagues have produced 30 research papers on a range of conditions but perhaps most particularly trichomoniasis in finches, paridae pox in great tits and Salmonella enteritica in passerine birds.

Trichomoniasis, caused by a protozoan parasite, has been known for many years in pigeons and doves and also in birds of prey, but in 2005 it emerged in finches, first causing necrotic ingluvitis, infection of the crop. ${ }^{1}$ Since then epidemic mortality has occurred every year in the late summer and early autumn in birds visiting garden feeding stations, and particularly in Greenfinches (Chloris chloris). In the first year this disease led to a reduction in greenfinch populations of $35 \%$ and in chaffinches of $20 \%$ in areas with highest reports of the condition. Before the outbreak these finch species were seen in around $80 \%$ of gardens yet in the years following first reports of the disease sightings have halved. ${ }^{2}$ Now in the UK the International Union for the Conservation of Nature (IUCN) Red list classifies the breeding greenfinch population as endangered. Spread to Europe seemed to occur in 2008 with the same A1 clonal strain of Trichomonas involved. It appears that year-round feeding of garden birds at stations such as bird tables and congregation of birds at such localities has led to the spread of this condition. ${ }^{3}$

What then of paridae pox? Various strains of avian pox have been reported as infecting wild birds in the UK for many years with house sparrows, starlings, pigeon and dunnock often affected with proliferative skin lesions. In 2006 a more severe form of the disease was noted most commonly in the great tit (Parus major). ${ }^{4}$ This form of the disease had been reported in Scandinavia as far back as the 1950 s and it seems that the spread to Great Britain may be through spread of an invertebrate vector via wind and inadvertent transportation. The condition has a significant effect on fledgling success and thus on the survival of juveniles but modelling suggests that at the current prevalence of $5 \%$ a substantial effect on wild populations is not occurring but might if prevalence increased to maybe $8 \%$.

The third condition under investigation by the ZSL group is salmonellosis which causes granulomas in the oesophagus, liver and spleen particularly of greenfinches and house sparrows. ${ }^{5}$ These species are considered to be reservoirs of Salmonella enteritica typhimurium and while trichomonas and poxvirus have increased in number, salmonellosis seems to have decreased recently. It may be
Volume 4 Issue 2 - 2019

\author{
David LWilliams \\ University of Cambridge, UK
}

Correspondence: David L Williams, Cambridge Veterinary School, University of Cambridge, Mafdinegley Road, Cambridge, UK,Emaildlw33@cam.ac.uk

Received: April 23, 2019 | Published: April 25, 2019

that the birds have developed herd immunity to the disease, but we should not be complacent, as these bird-adapted bacteria can give rise to human outbreaks. ${ }^{6}$

With investigations of these three major diseases in British wild birds not to mention several others for which we do not have space here and investigations into disease in other garden wildlife from frogs to hedgehogs Becki has made a significant contribution to wildlife health and should be warmly applauded.

\section{Acknowledgments}

None.

\section{Conflicts of interest}

Author declares that there is no conflict of interest.

\section{References}

1. Lawson B, Cunningham A, Chantrey J, et al. Epidemic finch mortality. Vet Record. 2006;159:367.

2. Lawson B, Robinson RA, Colvile KM, et al. The emergence and spread of finch trichomonosis in the British Isles. Phil Trans $R$ Soc $B$. 2012;367(1604):2852-2863.

3. Lawson B, Robinson RA, Toms MP, et al. Health hazards to wild birds and risk factors associated with anthropogenic food provisioning. Phil Trans $R$ Soc B. 2018;373(1745):20170091.

4. Lawson B, Lachish S, Colvile KM, et al. Emergence of a novel avian pox disease in British tit species. PLoS ONE. 2012;7(11):e40176.

5. Lawson B, Howard T, Kirkwood JK, et al. The epidemiology of salmonellosis in garden birds in England and Wales, 1993 to 2003. Ecohealth. 2010;7(3):294-306.

6. Lawson B, De Pinna E, Horton RA, et al. Epidemiological evidence that garden birds are a source of human salmonellosis in England and Wales. PLoS ONE. 2014;9(2):e88968. 